\title{
Courtship Behaviour of Lesser Scaup
}

\section{by Frank Brazier, Regina}

While driving by Wascana Lake in Regina on the morning of April 23, 1963, I noticed that the large number (about 170) of Lesser Scaup which had been there the previous day had either moved out of the area or cver to the Waterfowl Park and that only about 12 were left on the lake. Close against the near shore was a group of six consisting of one hen and five drakes. Some sort of courtship display was going on so I stopped to watch. Snuggled up against the hen was a drake, evidently the favoured one, but he did nothing except remain as close to her as possible; the hen kept tossing her head upwards in spasmodic jerks, opening and closing her bill meanwhile. The four rejected swains would edge in closer and whenever they got within two or three feet the hen would lower her head, stretch out her neck and drive furiously forward, opening her bill at the same time. I was too far away to hear any sounds from her, but she looked like an infuriated goose attacking and perhaps she too was hissing. The rejected drakes would move off somewhat casually, their dignity unruffled by the hen's hysteria, when she would return to the chosen one, and continue her head tossing. She interrupted this only to chase off the others, and twice she dived, re-appearing to continue her display, at which time her drake would swim calmly to her side, and remain snuggled up very closely, now at her side, now under her ohin. I watched this for ten minutes and it was still going on when I left.

In the last few days we have also noted little groups of Lesser Scaup in flight over the lake, consisting of several males and one female, and these are presumably the so-called "rape flights" with the males pursuing the excited female. Althougn rafts of Lesser Scaup always stay for some time in migration at the Waterfowl Park and on Wascana Lake, courtship behaviour is not often described.

\section{Winter Feeding Habits of Bohemian Waxwings}

\section{by Dorreene Inglis, Estevan}

Probably the best fed and the most. photographed wild birds in Western Canada this past winter were Bohemian Waxwings which spent the cold months at Estevan, Saskatchewan.

In past years, flocks of waxwings have stopped for a while in Estevan during their flight south. In the grounds outside St. Joseph's Hospital near some evergreens and a big elm, is a large crab-apple tree. Until this winter of 1962-63, once the apples were finished, the waxwings were soon on their way to winter quarters elsewhere. This year Sister Doloretta, whose record-office windows are very close to these trees, decided to augment the bird food available outdoors. A bird lover, Sister had Audubon books in her personal library which suggested dried fruits. She offered raisins, which they ate. Then she mixed raisins and bits of prunes. However, she watched with amusement as they picked out the bits of prunes and discarded them in order to get at the raisins. During her early observations of the birds feeding, she noticed that after taking a raisin, often a bird would fly immediately to a snow bank as if it needed some moisture to help it swallow the fruit. From then on, she washed the sticky raisins first in hot water to separate them, and then in cold water. Further, she discovered that they had a preference for lightcolored raisins. She first dropped the raisins on to the ground outside her window, then she put them on the outside window ledge and it was not too long until the birds were eating the raisins out of her hand in the open window.

These birds stayed all winter, eat- 